\title{
The Security Issue of the South China Sea
}

\author{
Maj Christian R. Sanchez Hernandez
}

Keywords: China, South China Sea, Island building, Exclusive Economic Zone, Maritime Law

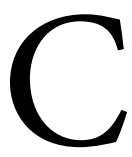
hina's expansion in the South China Sea is not only important for today's political climate, but also crucial in the international relations arena. China has been able to claim nearly eighty percent of the South China Sea, affecting one third of the global maritime trade routes that occur in the South China Sea. Additionally, building up shoals and islets to expand China's Exclusive Economic Zone beyond its natural coastal shores and militarizing them, add to the destabilization of the region. Realistic international relation theory asserts that China is currently manifesting and using coercive diplomacy and military projection as instruments of power.

What situation creating a security issue? In its simplistic form, China claims the sovereignty over South China Sea, and the resources that lie within it, a contention which has existed between adjacent coastal countries since the mid $20^{\text {th }}$ century. "In 1947 the Nationalist government of the Republic of China began to publish maps with a U-shaped series of lines in the South China Sea delineating its maritime boundaries." ${ }^{1}$ The "nine dash line" far exceeds the Exclusive Economic Zone (EEZ) two hundred nautical miles off a state's coastal boundary, effectively encroaching in other states sovereign waters in the South China Sea. As a result of the nine-dash line, should China claim sovereignty of nearly eighty percent of the South China $\mathrm{Sea}^{2}$, it may inhibit freedom of maritime navigation. Currently, "South China Sea accounts for at least a third of the global maritime trade." 3 The lack of freedom of maritime trade in the South China Sea not only impacts Philippines, Malaysia, Vietnam, Indonesia, and Taiwan in their ability to trade and import/export supplies, it impacts US national security for the same reasons. President Biden stresses the importance of Global Security in which, "Democratic nations are also increasingly challenged from outside by antagonistic authoritarian powers." The attempts by China to expand their EZZ is furthered by claiming jurisdiction of the Spratly and Paracel islands, islets and shoals. This not only effectively extends their EEZ, but also enables a broadened military presence. China's claim to the islands complies with "general provision of the 1982 United Nations Convention on the Law of the Sea (UNCLOS), however, under Article 121, "it requires that islands support human habitation or economic activity before they can accrue a full two-hundred-mile EEZ rather than twelve." ${ }^{5}$ By building islands and establishing military posts and airfields manned by a few military personnel, 
China is, to a certain degree, legitimizing its claim and gaining control over South China Sea, by using the legal definition of what constitutes a habitable island per UNCLOS.

\section{International Relations Theory}

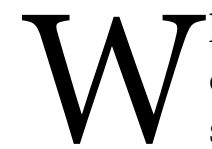
hen considering the tenants of International Relationship Theory China has displayed many tenets of a Realist perspective. China's projection into the South China Sea demonstrates many complimentary concepts of realism, such as, Interest, Protect and enhance power, Coercion, among others. Evidence to support China's coercive tactics in the South China Sea has been seen in, its willingness to deploy "combat-ready patrol ships to escort fishing vessels." China's expansion into the South China Sea creates a security issue at an international level due to the encroachment of the Economic Exclusion Zones of Vietnam, Malaysia, Philippines, and Indonesia. ${ }^{7}$ And why not? China is simply exerting Morgenthau's definition of power, "man's control over the minds and actions of other men" and "a psychological relation between those who exercise it and those over whom it is exercised." China is using the full range of the Instruments of Power (often articulated as the DIME principals; Diplomatic, Information, Military, Economic) to assert control over vast portions of the South China Sea and project economic influence and military might. One such example is China's show of coercive diplomacy to impose economic sanctions that affected the Philippines's tourism and fruit exports causing the then-President Benigno Aquino III to negotiate a withdraw from the Scarborough Shoal. ${ }^{9}$ China is applying a sort of geo-strategy in the South China Sea to apply power to the region and effectively control sea lanes. ${ }^{10}$ In essence, China is building its Latent power through strategic resources based in the South China Sea as it is, "a long-standing task for China to safeguard its maritime rights and interests." 11

\section{Proposed United States Led Strategy}

he United States is poised to lead
an international strategy coun-
tering China's South China Sea effort; however, it must be both deliberate and legitimate. This is an international dilemma and the United States must first integrate UN and ASEAN partners to begin collaborative development of strategies that would be effective against China. China has been able to successfully exploit international law to claim jurisdiction and sovereignty over the South China Sea, therefore, it is imperative that the United States, along with regional allies, employ the same legal system to de-legitimize China's claim and therefore, apply pressure for China's recession of the encroachment. Thus, the lynchpin in the strategies' mechanism is sound diplomacy. Such diplomacy must first to regain and maintain a balance of power between nations in the South China Sea. Once China's claim over the nine-dash line has been nullified by due process, (not to imply that it has ever been legit- 
imized), the use of the economic instrument of power can enforce the precedent by applying sanctions for Chinese vessels in foreign EEZs. Undoubtedly, this would create much consternation and militarily tensions between China, the United States, and adjacent nations that share the waters of the South China Sea. This would lead to military use of the instrument of power. Ideally, it would require Vietnam's, Malaysia's, Philippines, Indonesia's, and Taiwan's military with United States support to deter Chinese aggression in the region. The threat of hostilities would have an inverse relation to the effectiveness of China's legal claim, the United States must be prudent to ensure the conflict is rightfully perceived an ASEAN conflict with United States, UN, and EU in support, rather than a United States versus China fight. Unfortunately, not all ASEAN countries have a strong and robust military, and as such would be augmented with United States Navy ships or other United States military resources, presenting a large optics issue. At a glance, it may seem that the United States would be the predominant force in the conflict and care must be taken to avoid-with a certain degreethe world view of the US making it an American conflict. Strategic use of the remaining instrument of power; information. The United States and its allies must work diligently to reinforce a culturally sensitive and appropriate narrative that places ASEAN nations and their interests first.

\section{What Does Success Look Like?}

0 uccess looks like China receding from the Spratly Islands and islets, its claim of the South China Sea, with China abandoning the "nine dash line," and a negotiated treaty between China and neighboring states like Vietnam and the Philippines, (primarily with Vietnam), over the Paracel Islands. Yes, this outcome can be considered a "happily ever after" or best-case scenario in favor of regional equilibrium and stabilization of the region.

\section{Conclusion}

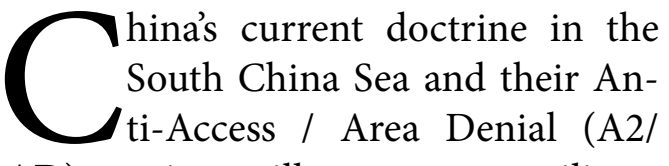
AD) tactics, will cause any military movement by ASEAN nation(s) with (or without) the US will be taken as an infringement on China's self-declared legal jurisdiction, and be seen as an act of war. International arbitration over China's claim of the South China Sea has taken place through established and accepted international court proceedings. In July 2016 the tribunal ruled that China had no legal basis for the area within the nine-dash line. ${ }^{12}$ Yet, China has blatantly dismissed the ruling and continues to press forward with territorial claims in the South China Sea. ${ }^{13}$ Unfortunately, defining success as a balance of power and resources in the South China Sea among all countries that share the sea, then Chinese leadership would lose face and tarnish the legitimacy in the eyes of the Chinese people. ${ }^{14}$ The situation is escalating at a 
rapid pace and offers difficulty to find gent diplomatic action or armed conany middle ground. As tensions rise the flict grows narrower and narrower. hope for a resolution that avoids strin-

\section{Endnotes}

1 Dutton, Peter. "THREE DISPUTES AND THREE OBJECTIVES: China and the South China Sea." Naval War College Review 64, no. 4 (2011): 42-67. Accessed June 24, 2021. http://www.jstor.org/stable/26397243.

2 Zhao, Suisheng. "East Asian Disorder: China and the South China Sea Disputes." Asian Survey, 60, No.3 (2020): 491.

3 Riyaz Ul Khaliq, "'3 reasons' China tries to control South China Sea," Anadolu Agency, Accessed June 24, 2021. https://www.aa.com.tr/en/asia-pacific/3-reasons-chinatries-to-control-south-china-sea/2157110

4 Biden, Joseph R. Interim National Security Strategic Guidance. Washington, D.C.: The White House, March 2021.

5 Dr. Stephen Burgess, "Confronting China's Maritime Expansion in the South China Sea: A Collective Action Problem," accessed 23 June 2021, URL: https://www.airuni versity.af.edu/JIPA/Display/Article/2331176/confronting-chinas-maritime-expan sion-in-the-south-china-sea-a-collective-actio/

6 Zhao, Suisheng. "East Asian Disorder: China and the South China Sea Disputes." Asian Survey, 60, No.3 (2020): 493.

7 Ibid.

8 Nation, R. Craig. "National Power." In The U.S. Army War College Guide to National Security Issues, Volume I: Theory of War and Strategy, 5th ed., edited by J. B. Bartholomees, Jr. Carlisle Barracks, PA: U.S. Army War College, 2012: 148.

9 Zhao, Suisheng. "East Asian Disorder: China and the South China Sea Disputes." Asian Survey, 60, No.3 (2020): 495.

10 Burgess, "Confronting China's Maritime Expansion in the South China Sea: A Collective Action Problem."

11 Fravel, M. Taylor. "China’s 'World-Class Military' Ambitions: Origins and Implications," The Washington Quarterly, 43, no. 1 (Spring 2020)

12 Ibid. 501.

13 Ibid.

14 Ibid. 503. 